\title{
Stakeholder perspectives on organizational identity: searching for a relationship approach
}

Laura Illia

ICA - Institute for Corporate Communications (University of Lugano, Switzerland)

13, Giuseppe Buffi

6900 Lugano - Switzerland

tel.: +41919124632 // fax: +41919124647 // e-mail: Laura.Illia@lu.unisi.ch

URL: www.unisi.ch

Francesco Lurati

ICA - Institute for Corporate Communications (University of Lugano, Switzerland)

13, Giuseppe Buffi

6900 Lugano - Switzerland

tel:+41919138582 // Fax +41919124647 // e-mail: Francesco.Lurati@,lu.unisi.ch

URL: www.unisi.ch // www.mscom.unisi.ch

This paper will be published, see: Illia, L. Lurati, F., 2005, Stakeholder Perspective to Organization's Identity: Searching for a Relationship Approach". Corporate Reputation Review. Palgrave, 8 (4), forthcoming

\section{Key words:}

Relational nature of identity, looking-glass process, identity discrepancy, external images, stakeholder theory, situational approach

\begin{abstract}
The present paper discusses the substantial difference for practice of current models of organizational identity which consider directly and indirectly the looking-glass process of organizational identity. The paper pinpoints that some models represent a first useful step for an analysis of external interpretations of the organizations and that others represent an in-depth view of external images with consequences on the organization. Examples of the usefulness of the models are developed as they are reread in the light of three different approaches of stakeholder theory which provide an understanding of the different levels of analysis of stakeholders' external interpretations of the organization: the broad, the narrow a priori and the narrow situational. An exploration of the interrelations between identity and stakeholder fields is therefore provided.
\end{abstract}




\section{Introduction}

The relational nature of organizational identity is mainly discussed in two different ways. On one hand, it is used to distinguish the different components of organizational identity and to show how the identities of organizations differ from each other (Makey and Whetten 2002). On the other hand, it is used it to discuss the looking-glass process from which organizational identity emerges (Hatch and Schultz 2000) and from which it is possible to achieve organizational effectiveness conjoining what the organization is, and what its external interpretations are.

Considering the relational nature of organizational identity in terms of this second meaning, the paper looks at models of relational nature in the light of the concepts discussed in the stakeholder tradition of study. The aim of this reflection is to understand the usefulness of such models in practice. When should which model of the relational nature of identity be used? Is there any substantial difference between them that is relevant when I apply them in practice? It is important to underline that we choose to relate to stakeholder theory since, as Grunig and Hunt (1994) and Grunig et al (2002) state, this tradition of study originally aimed to deepen understanding of the relationship nature of organizations. Since it provides a deep understanding of the stakeholder relationship, it allows us to better understand external interpretations of the organization. As we will see, there are three different approaches to stakeholder relationships (Windson, 1992, and Mitchell Agle and Wood, 1997; Winn 2001) : the broad, the narrow a priori and the narrow situational. Each one provides different levels of analysis of external interpretations of the organization and might therefore be used differently. Consideration of the relations between identity and these three stakeholder traditions of study helps us to understand in which terms authors discuss the relational nature of organizational identity. In the first part of the paper, a short overview of the different meanings of the relationship concept of organizational identity will be provided. It will show that studies on the interrelationship between identity image, reputation and identification discuss it in terms of the looking-glass social -construction process. In the second part, the main three stakeholder approaches will be discussed: In particular this part will explain how they differ and contribute to managing the relational nature of organizations. In the last part, organizational identity literature will be reconsidered in terms of stakeholder perspectives. Organizational identity models will be categorized into three main groups of stakeholder approaches in order to explore the interrelations between them and to discuss the substantial difference for practice of current models on the relational nature of organizational identity 


\section{The relational nature of organizational identity and models that discuss it}

In organizational identity literature, authors mean different things when they refer to the relational nature of identity. It is therefore important to illustrate what these meanings are in order to clarify the approach of our paper.

The relational nature of organizational identity is a concept that can be traced back from the literature on the identity of individuals. The identity of individuals consists of (a) a personal identity, or individual characteristics such as gender; (b) a social identity, or the membership in a social category such as the family or the organization where the individual is employed; (c) a relational identity, or role characteristics that define the function one has, such as son or director (Brewer 2003). As Makey and Whetten write, the translation of Brewer's arguments to the organizational level means that authors on organizational identity have developed an understanding of "how organizations define themselves in terms of what they share in common with other organizations and how they are different from all other organizations." (Makey and Whetten 2002: 397). In particular, the relational nature of organizational identity is used to identify how organizations are different from one another (Lewellyn 2002).

Moreover, the relational nature of organizational identity is a concept that is used in a broader way to refer to the looking-glass social-construction process of identity that shows how the identity of organizations has a relational nature marked by a conflict of perception that may emerge between the two parties. As Albert and Whetten state in their original definition of organizational identity, organizations define what is core, distinctive and enduring in their identity according to the degree of identity discrepancy perceived over time in relationships established with external constituencies: "organizational identity is formed by a process of ordered inter-organizational comparison and reflections upon them over time "(Albert and Whetten 1985:273). This relational aspect is based on the assumption that the nature of organizational identity emerges from the looking-glass construction process of identity formation as enunciated by Cooley (1902). As Hatch and Schultz (2000) state, authors who discuss the looking-glass process are those who consider how organizational identity is experienced in organizations from a mirroring process of the external image and who focus on understanding how to fill the gap between what organizations and external images are. Organizations compare themselves with others whose feedback is integrated to decrease the discrepancy perceived between what the organization is and how it is perceived externally. It is possible to assert that the 
authors who discuss the relational nature of identity in these terms belong to the fourth evolutionary phase characterizing the research into identity as discussed in the review by Balmer and Soenen (1997). Thus, this fourth phase includes authors who focus on the interrelationship between identity, image and reputation, in other words on how to conjoin the external image with organizational identity and on how identity can be managed as a strategic management tool to fit externalities and achieve organizational effectiveness ( Balmer and Soenen 1997). It is important to underline that the relational nature of organizational identity which refers to the looking-glass process is not discussed only in studies that analyze the mirroring process directly, but also in studies which analyze the reflecting effect it has on organizational identity. The authors of these other studies do not discuss how organizational identity fills the gap between the organization and its images, but rather how organizational identity fills the motivational and commitment gap. They study what Hatch and Schultz (2002) call the reflecting process of identity, the process of how identity changes its characteristics according to the interpretation of the mirrored images and how members experience themselves as an organization. It is possible to assert that the authors who discuss the relational nature of identity in these terms belong to the future phase of research on identity, as discussed by Balmer and Soenen (1997). Indeed, this future phase includes the authors who examine how organizational identity influences members' identity and how organizational identity and members' identification can help to achieve organizational effectiveness when technological development and transformations reshape the forms of organizations (Balmer and Soenen 1997).

As anticipated in the introduction, when we discuss the relational nature of identity we do not refer to the relational identity type, but to the mirroring effect of the looking-glass process. In the following two paragraphs, we first present the authors who consider the mirroring effect in the interrelationship between identity image and reputation, and secondly the authors who consider how the mirroring effect is reflected in organizational identification.

\section{Relational nature of identity in studies on identity, image and reputation.}

Many authors discuss the relational nature in terms of how to reduce the gap between identity, image, and/or reputation. The debate which emerges from the different conceptualizations of image and reputation goes 
beyond the scope of this paper. What is interesting for this article is to understand that all these studies consider external stakeholders' relationships in the identity- formation mirroring process. For example, Dutton \& Dukerich (1991) developed an empirical study on organizational identity and organizational image which gives evidence of the importance of identity discrepancy in relationships with external constituencies as a dynamic of identity formation. This study shows that organizations integrate external issues relevant from the constituencies' point of view because they are willing to correct the discrepancy. The selfrepresentation of an organization is the result of a formulation of the self through interactions inside and outside the organization. Other empirical studies have been developed to underline the importance of reducing the gap in identity perception between the organization and its constituencies. Among these are, for example, the AC2ID test (Balmer 2001), Personification metaphor (Davies, Chun, da Silva \& Roper 2001), Reputation Quotient (Fombrun, Gardberg \& Sever 1999).

Conceptual models which underline the multilevel features of organizational identity stressing its relational nature have been developed by, for example, Albert and Whetten (1985) and Pratt \& Foremann (2000). Relationships established by the organization with others create multiple classifications of organizational identity according to different constituencies, which is what creates as many levels of identity as there are relationships. Like individuals, organizations classify themselves according to the situation of discrepancy perceived within the relationship. Also Child and Rodriguez (1991) and Gioia \& Shultz \& Corley (2000) underline that organizations define the boundaries of their identity according to the parties involved in social relations. Kennedy (1977); Dowling (1986); Abratt (1989); Alversson (1990); Fombrun 1996; Balmer 1998; Stuart ( 1999); Balmer \& Gray (1999); Fombrun \& Rindova (1999), and Rindova (1997) discuss the centrality of relationships with external constituencies as well. Their viewpoint is that discrepancy in relationships, when lowered, is the key element in creating a positive image among all stakeholders.

\section{Relational nature of identity in studies of identification}

Many authors discuss the relational nature of how identity fills the motivational and commitment gap, creating higher identification as well as solving role conflicts and problems of inter-group relations. As explained earlier, this literature is focused on the internal gap within the organization and does not aim to study the issue of identity discrepancy perception with all constituencies. Yet, interpreting Ashforth and Mael's review of organizational identification literature (1989), it is possible to draw the conclusion that 
these authors study identification in terms of how the looking-glass process at the organizational level impacts on how members define their own identity. To understand that, it is necessary to briefly present Ashforth and Mael's (1989) explanation of the existence of two main approaches to organizational identification. One approach conceptualizes identification as the internalization of values and therefore is a synonym of commitment. The other defines identification as the process helping the organization member to classify himself within the organization. The former view considers that identification creates the "I believe", since it directly impacts on members' motivation, whereas the latter considers that identification creates the "I am", since it creates the acceptance of social categories by employees, which only indirectly impacts on their motivation. Interpreting Ashforth and Mael's review, it is possible to understand that this second approach to organizational identification bases its studies on the relational nature of identity. In fact, this view underlines that organization members find commitment and motivation because they know what their place is within the organization and this is what allows them to acquire self-esteem(Jacques 1955). As some empirical studies on organizational identification show, according to this second approach, organization members preserve their self-esteem according to how their role in the organization is affected by the external prestige of the organization. In other words, organization members perceive the external discrepancy of the organization's identity with its constituencies as relevant for their own identities. For example authors such as Mahel \& Ashforth (1992); Dutton, Dukerich \& Harquail (1994); Elsbach \& Kramer (1996); Carrol \& van Riel 2001; van Riel, Smidts and Pruyn (2001) specifically aim to give evidence of what makes organizational identification high or low, and also discuss identity discrepancy with external constituencies' perceptions as a key element of the looking-glass process. Organization members perceive the prestige of the organization as it is externally conceived. There is the tendency among organization members to have high or low identification with the organization in favour of their personal identities, depending on the prestige of the organization as well as on other factors. Organization members create the "I am" according to a social categorization that includes comparison at the organizational level. When the comparison with external constituencies creates a high identity discrepancy, identification is highly impacted.

So far we have shown how models in organizational identity theory discuss the relational nature of organizational identity. To reconsider them in the light of the different approaches in stakeholder theory, we 
first present what these approaches are, and what their contribution is to the understanding of the relational nature of organizations.

\section{Stakeholder theory approaches: first or deep insight into external interpretations of the organization}

From the debate in stakeholder literature, it emerges that there are three main traditions which study the relational nature of organizations: the broad, the narrow a priori and the narrow situational approaches. According to Windson (1992) and Mitchell, Agle and Wood (1997), the broad and the narrow divergent perspectives on the relational nature of organizations emerge from a different interpretation of Freeman's definition of a stakeholder as "any group or individual who can affect or is affected by the achievement of the organization's objectives" (1984: 46). In brief, the broad approach considers the relational nature of organizations in terms of the mass of public opinion, the narrow a priori approach considers it in terms of primary and secondary stakeholders, and the narrow situational approach considers it in terms of the organization's stakeholder relationships which have consequences on the organization. Differentiating between the three approaches is relevant for the purpose of this paper because it enables us to understand that the consideration of external stakeholder images has different implications for the practice of communicational programs. As Grunig J.E. and Hunt state (1984), managing the external relations of organizations means managing the external images, since the identification of stakeholders helps us to understand the external interpretations that there are of the organization. Differentiating between the broad and narrow a priori approaches and the narrow situational approach shows, on one hand, that the first two views are very valuable when it is necessary to have a first insight into the image that exists outside the organization, and on the other, that the third one is very useful when it is necessary to have an in-depth insight into which external stakeholder has an image that may contribute to organizational effectiveness, if integrated into communicational programs. Indeed, as Grunig J.E. shows (1993), the consideration of organizational image not only as a mass cognitive attribution but as a relational behavioural reality helps us to understand which images have consequences on the organization and an influence on the perceptions of others. These images have to be taken into consideration when establishing long-term communicational programs since their integration is very relevant for organizational effectiveness in the long term. These arguments will be presented step by step in the next paragraphs when presenting each of the approaches in detail. 


\section{The broad and narrow a priori views on stakeholders: first insight into external perceptions}

According to Windson (1992) and Mitchell, Agle and Wood (1997), authors who interpret the definition of stakeholder in a broad view consider that almost anyone can be a stakeholder since every entity with a stake in the organization may be considered relevant. For this view, see, for example, Berman, Wicks, Kotha and Jones (1999) and Luoma and Goodstein (1999). This view does not address stakeholders from a relational point of view since it considers all stakeholders to be relevant independently of the relationship they have with the organization.

The narrow view differs from the broad one in that it distinguishes between primary and secondary stakeholders (Windson, 1992, and Mitchell Agle and Wood, 1997). Although not widely discussed, this narrow a priori approach to stakeholders is what Winn (2001) calls the a priori categorization of stakeholder impact. The narrow a priori view authors - such as, for example, Clarkson 1995; Davenport 2000; Hillman, Keim, Luce (2001); Bendheim, Waddock and Graves (1998); Waddock \& Graves (1997); Jawahar and Mclaughlin (2001), and Esman (1972) - develop models which consider a predefined number of key stakeholders as being relevant for organizations. Their relevance is independent of the situation, in that each model proposes a set of relevant stakeholders based on reasons which are not contextual or situational. This is why the narrow a priori view does not differ in nature from the broad view. As Grunig and Repper underline in the nested model of stakeholder segmentation (1992), the approaches which give an objective view of stakeholders are very useful for conducting an initial analysis of organizational relationships since they clarify existing external perceptions of the organization. Interpreting Grunig and Reppper's words, the broad and the narrow a priori approaches to stakeholders are a useful first step in identifying external perceptions, which has, however, to be followed by a more in-depth approach.

One of the best-known authors with a narrow a priori view on stakeholders is M.B.E. Clarkson. Clarkson (1995) considers employees, shareholders, customers and suppliers, and public entities primary stakeholders because of the typical corporate issues they are interested in. Some of them are social, others are not social issues. These stakeholders are relevant also because they have a continuing participation in the organization's activities and have control over critical resources, without which the organization would not be able to survive. Many studies have been developed on the basis of his definition of primary stakeholders. 
For example, Bendheim, Waddock and Graves (1998) studied best practices with respect to these five key stakeholder categories, while Waddock \& Graves (1997) explored the interdependence of the quality of management of primary stakeholders and the quality of performance.

Another author with a narrow a priori view on stakeholders is Davenport. Communities, consumers, employees, suppliers and investors are primary stakeholders according to their commitment and to their legitimate claims on organizational corporate citizenship behavior (Davenport, 2000). Also Hillman, Keim, Luce (2001) consider these four categories of stakeholders primary; however, they do not provide any explanation for their relevance.

Jawahar and Mclaughlin identify stakeholder relevance based on the power stakeholders exert on the organization. By power, they mean control of the organization's critical resources, which is the way key stakeholders contribute to the basic needs of the organization. They then attribute stakeholder impact in the different phases of the organization's lifecycle (Jawahar and Mclaughlin, 2001). Basing their analysis on this principle, they consider shareholders, creditors and customers primary in the start-up stage; stockholders, creditors, employees and suppliers key stakeholders in the emerging-growth stage; employees, communities, trade associations, government and suppliers primary in the mature stage, and customers, creditors and stockholders together with employees and suppliers primary in the decline or transition stage.

Finally, Esman (1972) defines stakeholder relevance according to the type of linkages they have with the organization. In his opinion, stakeholders are relevant when they provide or control organizational resources, or when they have claims on the organization. Stockholders, government institutions, community leaders and boards of directors are key stakeholders because they provide and control the resources that enable the organization to exist (Enabling linkages); employees, unions and suppliers are key stakeholders because they provide inputs to the organization (Input functional linkages); customers are key stakeholders because they take outputs from the organization (Functional output linkage); professional associations and other organizations within the same context are key stakeholders because they face similar problems or share similar values with the organization (Normative linkage). Finally, other interest groups and intermediaries are key stakeholders because they have diffused interests and claims on the organization (Diffused groups).

The narrow situational view of stakeholder relevance: a deep insight into external perceptions 
The narrow situational approach, like the narrow a priori approach, defines stakeholder relevance according to relational criteria. However, unlike the former, it considers relational criteria that filter stakeholder relevance according to the contextual consequences which may emerge. This narrow approach to stakeholders is what Winn (2001) calls the situational categorization of stakeholders. Authors such as, for example, Mitchell, Agle and Wood (1997); Jonker \& Foster 2002; Grunig 1994; Savage, Nix, Whitehead and Blair (1991) deduce stakeholder priority according to the particular situation which the organization is in. They do not predefine a selected number of stakeholders, but some categories of stakeholder that are strictly related to the context of the organization. Models referring to the narrow situational view define the relevance of stakeholders according to issues that involve referential groups and the organization at that particular moment. Essentially, this is the main reason why the narrow situational view differs from the broad and narrow a priori ones. As Grunig and Repper underline in the nested model of stakeholder segmentation (1992), the approaches which give a subjective view of stakeholders are those which are most useful for obtaining a more in-depth view, after the first step of analysis of the external perceptions of the organization. Interpreting Grunig and Repper's words, the narrow situational view consists of a deeper analysis of external perceptions than the broad and the narrow a priori ones. As Grunig L.A et al. show (2002), differentiating between situational and non-situational approaches facilitates the distinction between relationships with stakeholders whose perceptions have and those with stakeholders whose perceptions do not have consequences on the organization. Indeed the situational approach allows us to identify which external relationships have perceptions which have consequences on the organization in the long term (Grunig 1993) and may influence the perceptions of others about an organizational issue. According to Grunig L.A et al. (2002), Grunig J.E and Repper (1992) and Grunig (1993) this is the only way to manage communication programs strategically. Essentially, considering the overall perception of the organization is useful as a first step, but does not help to solve concrete problems since it does not help us to understand which external images should actually be included in the long term.

Some of the best-known authors with a narrow situational view on stakeholders are Mitchell, Agle and Wood. These authors consider three main deductive criteria for stakeholder identification: power, legitimacy of claim and urgency (risk). Using these three criteria, it is possible to prioritize the organization's stakeholders according to their specific situations. Depending on the situation, stakeholders can be dormant, dangerous, demanding, dependent or discretionary. Analyzing Mitchell, Agle and Wood's models, Jonker 
and Foster (2002) discuss another two criteria for prioritizing stakeholders: criticality and rationality of claims. Their viewpoint is that these two criteria are very relevant elements influencing the outcomes of relationship with stakeholders.

Other authors with a narrow situational view are Savage, Nix, Whitehead and Blair. They discuss criteria impacting on stakeholder potential for threat and cooperation (Savage, Nix, Whitehead and Blair 1991), such as control of key resources, power over the organization, stakeholder proneness to take supportive or nonsupportive action and to form supportive or non-supportive coalitions. Depending on the situation, stakeholders can be: "mixed blessings", "supportive", "marginal” or "non-supportive".

Another well-known author with a narrow situational approach is Grunig J.E. He validated the situational theory of communication behavior (Grunig 1994), which discusses three variables impacting on the communication behaviors of stakeholders: problem recognition, constraint recognition and level of involvement. According to these criteria, stakeholders are relevant and are considered publics - groups or organizations who not only have an interest in the organization but, depending on the situation, have perceptions which can have consequences on the organization. Depending on the situation, stakeholders can be non-public or latent, aware or active publics.

\section{Rereading models of the relational nature of organizational identity exploring the interrelations with the stakeholder approaches}

We will now reconsider the authors who discuss the nature of relationships to see both how they discuss stakeholder relevance and which of these three stakeholder traditions they refer to. Following what was discussed above, rereading helps to identify which models of organizational identity in practice represent a first useful step for an analysis of external interpretations of the organizations, as well as which ones represent an in-depth view of external images with consequences on the organization.

In brief, in the next paragraph we explore the interrelationship between the models in organizational identity literature and the approaches in stakeholder literature presented above. Although the broad, the narrow a priori and the narrow situational approaches are not explicitly mentioned, models in organizational identity literature can be related to these traditions of study. In particular, as the following paragraphs will show, it is possible to identify some examples of approaches to stakeholder and identity areas of research. Examples of 
authors referring to the broad view are mainly those who consider reputation and external prestige. Examples of authors referring to the narrow approach are mainly those studying organizational image.

\section{The broad approach to stakeholders in organizational identity theory}

As outlined earlier, the broad approach considers stakeholders and their images independently of the consequences of the relationship they have with the organization. Authors in organizational identity literature who focus their attention on the interrelationship between identity and reputation or identity and external prestige can be traced back to the broad approach. Indeed, these authors developed models on the interrelationship between organizational identity and reputation and organizational prestige as the result of an interrelationship between what the organization is and what the overall evaluation of an organization is - the broad mass perception of the organization. The value of such models is that they permit a very first useful insight into the external overall interpretation of the organization. When applied, these models indeed help us to understand how to fill the gap with the broad external overall perception of the organization.

An example of a reputation model which refers to the broad approach is, for example, the Reputation Quotient (RQ) (1999). The RQ was developed with the final aim of filling the gap with the broad audience. It measures the perceptions of external groups who do not necessarily have any direct relationship with the organization or any direct consequence on it. Examples of models of organizational prestige - otherwise called construed external image - which are related to the broad approach are the models of identification by van Riel, Smidts and Pruyn (2001); Carrol \& van Riel (2001); Elsbach \& Kramer (1996). They include a conception of external prestige that considers how the images of those outside are interpreted internally by members. External prestige is conceived as the overall prestige that members perceive inside the organization. This prestige is not necessarily attributed to external stakeholders who have a consequence on the organization.

\section{The narrow a priori approach to stakeholders in organizational identity theory}

Some authors in organizational identity literature who focus their attention on the interrelationship between identity and image can be related to the second approach in stakeholder literature: the narrow a priori approach. Their studies consider that some stakeholder groups have images which are more important than others for the correction of identity discrepancies. In particular, they name a predefined number of 
stakeholders as central to the discussion of the gap between identity and image independently of the situation. Like the models referring to the broad approach, the ones referring to the narrow a priori view do not help us to understand the consequences the external images have on the organization. These models define external images outside the limits of current consequences. Indeed, although they propose filling the gap with specific stakeholder perceptions that, a priori, are relevant for the organization, they do not consider which stakeholder interpretations have current consequences on the organization.

Among these models there is, for example, the Ac2ID Test (Balmer 2001) which considers managers, employees, competitors, media and consumers the constituencies that are relevant for the gap test between the fives types of organizational identities - actual, communicated, conceived, ideal and desired identities. Moreover, the Personification Metaphor of Davies, Chun, da Silva and Roper (2001) defines customers and employees as the key constituencies for the discrepancy analysis of internal and external perception of the seven dimensions of corporate personality: Machismo, Informality, Ruthlessness, Chic, Competence, Agreeableness, and Enterprise. There are also some conceptual models referring to the principle of primary stakeholders. Fombrun (1996) defines employees, customers, community and investors as key constituencies in his model of corporate reputation.

\section{The narrow situational approach to stakeholders in organizational identity theory}

The authors in organizational identity literature who focus their attention on the interrelationship between identity and image can be related to the third approach in stakeholder literature: the narrow situational approach. These studies consider, even though only indirectly, that there are some specific stakeholders who, in some specific situations and contexts, are particularly important in filling the gap between image and identity. Similarly, like the models that refer to the second approach, they also consider that some stakeholders are more important than others for correcting identity discrepancies. Unlike the second approach, however, this third approach considers stakeholder relevance according to the organization's contextual situation. What is important to underline is that these authors do not explicitly refer to a narrow situational approach to stakeholders, nor to the advantages of one.

Dutton and Dukerich (1991), for example, focus on how the Port Authority of New York and New Jersey adapts its image and identity according to contextual issues which somehow threaten its organizational identity. In this sense, they indirectly define issues as the basic element that defines which stakeholders are 
more relevant than others for organizational identity. Moreover Rindova (1997) relates the concept of the selection of an organization's image not to stakeholder typology, but to stakeholder communication behavior. She hints at Grunig's situational principles. Finally, Gioia, Schultz and Corley (2000) base their concept of identity instability on contextual issues. They therefore indicate that stakeholder relevance is based on a situational principle.

\section{Conclusion: Usefulness of models of the relational nature organizational identity}

In the light of the theoretical discussions we have developed in this paper, the following question becomes rhetorical: "Is it more effective to provide practitioners with models that tell them how to shape organizational identity toward an external overall interpretation of the organization? Or is it better to supply them with models that show them how to shape organizational identity toward external images with consequences on the organization and thus to influence overall perception?" The main thing we learn from the stakeholder tradition is that the definition of the overall interpretation of the organization is very useful, but is only a first step in the exploration of external perceptions. This first step has to be complemented with the identification of which specific images have consequences on the organization and have an influence on the images of others. Only in this way is it possible to strategically manage the external perception of the organization and to run long-term communication programs. It was interesting to note that the majority of studies only indirectly refer to this tradition within stakeholder theory: no explicit reference is made, either to the approaches or to their advantages. This was unexpected since those studies underline the relationship nature of organizational identity. In the light of these considerations, we believe that research and practice in organizational identity would benefit both from direct reference to the stakeholder tradition and from further work to develop the few attempts referring to the narrow situational stakeholder approach that have been made so far. While beyond the scope of this paper, these elements provide a basis for future research.

\section{References}

Abratt, R. (1989) “A New approach to the corporate image management process”. Journal of Marketing Management. 5(1). pp. 6376.

Albert, S. \& Whetten, D. (1985) Organizational identity”. In Cumming L.L. \& Staw, B.M. (Ed.) Research in organizational behaviour. Vol 7. Greenwhich: JAI Press. pp.1-52. 
Albert, S., (1977) “Temporal comparison theory”. Psychological Review. 84(7). pp. 485-503.

Albert, S., (1998) “The Definition and the Metadefinition of Identity”. In Whetten D.A., \& Godfrey, P.C., (Ed.) Identity in organizations. Building theory through Conversations. Thousand Oaks: Sage Publications.

Alversson M. (1990) “Organization: From Substance to Image?”. Organization Studies. 11(3). pp. 373-394.

Ashforth B.E. \& Mael F. (1989) "Social Identity Theory and the Organization”. Academy of Management Review. 14(1). pp. 20-39.

Balmer J.M.T. \& Soenen, G.B. (1997) "Operationalising the Concept of Corporate Identity: articulating the Corporate Identity Mix and the Corporate Identity Management mix", Working paper department of Marketing, December, University of Strathclyde.

Balmer J.M.T., (1998). “Corporate Identity and the Advent of Corporate Marketing”. Journal of Marketing Management. 14. pp. 963-996.

Balmer J.M.T., Gray, E.R., (1999)"Corporate identity and corporate communications: creating a competitive advantage". Corporate Communications: An international journal. 4(4). pp. 171-176.

Balmer, J.M:T:, (2001) From the pentagon : A new identity Framework”. Corporate Reputation Review. 4(1). pp. 11-22

Bendheim L.C., Waddock, S.A., \& Graves, S.B., (1998) "Determining Best Practice in Corporate-Stakeholder Relations using Data Envelopment Analysis". Business \& Society. 37(3). pp. 306-338.

Berman, S.L., Wicks, A.C., Kotha, S., Jones, T.M. (1999) "Does Stakeholder Orientation matter? The relationship between stakeholder management models and firm financial performance". Academy of Management Journal. 42(5).pp. 488-506.

Brewer, M.B. (2003) “Optimal Distinctiveness, Social Identity, and the self”. In Leary, M.R. \& Tangney , J.P. (eds.) Handbook of Self and Identity. New York: The Guilford Press

Brown, A. D. \& Starkey, K. (2000) “Organizational identity and learning: a psychocynamic perspective”. Academy of management review. 25.1. pp. 102-120.

Cooley, C.H. 1902. Human Nature and the Social Order. New York: Schriben

Child J., Rodrigues, S., (2001) "Social identity and Organizational Learning”. Chapter prepared for Easterby-Smith M. and Lyles M.A. (Eds.) Handbook of Organizational Learning. Oxford: Blackwell (Forthcoming).

Clarkson, M.B.E., (1995) “A stakeholder framework for analysing and Evaluating corporate social performance”. Academy of management Review. 20(1). pp. 92-117

Davenport, K. (2000) "Corporate citizenship: a Stakeholder Approach for defining Corporate Social Performance and Identifying Measures for Assessing it”. Business \& Society. 39(2). pp. 210-219.

Davies, G., Chun, R., da Silvia, R.V., and Roper. S., (2001). "The personification metaphor as a measurement approach for corporate performance". Corporate Reputation Review. 4 (1), pp.113-127.

Dowling, G. (1986) “Managing your corporate images”. Industrial Marketing Management. 15. pp. 109-15.

Dutton J.E. \& Dukerich, J.M. (1991) "Keeping an eye on the mirror: image and identity in organizational adaptation". Academy of Management Journal. 34.3. pp.517-554

Dutton J.E., Dukerich J.M., Harquail C.V., (1994) “Organizational images and member identification”. Administrative Science Quartelry. 39(2). pp. 239-263.

Elsbach, K. D., Kramer, R.M. (1996)" Members' responses to organizational identity threats: Encountering and countering the Business Week rankings". Administrative Science Quarterly. 41 (3) pp. 442 -476.

Erickson, E.H., (1980) Identity and the life cycle. New York: Northon.

Esman M.J., (1972) “The elements of institution Building”. In Eaton, W.J., (Ed.) Institution Building and Development . Beverly Hills: Sage. pp. 19-40.

Festinger, L. ( 1954) “A theory of social comparison process”. Human Relations. 7. pp. 117-140.

Fombrun C.J., Gardberg, N.A., Sever, J.M. (1999) “The Reputation Quotient SM: A multi-stakeholder measure of corporate reputation”, Journal of Brand Management, 7(4),pp. 241-255.

Fombrun, C.J. (1996), Reputation. Realizing Value from the Corporate Image. Boston: Harvard Business School Press. 
Freeman, R.E. (1984) Strategic management: a Stakeholder approach. Boston: Pitman

Gioia, D.A., \& Schultz, M. \& Corley K.G. (2000) Organizational identity, image and adaptive instability”. Academy of Management Review. 25.1.pp.63-81.

Goffman, E. (1959) The presentation of self in everyday life. New York: Doubleday.

Grunig, J.E. (1994) “A situational theory of publics: conceptual history, recent challenges, and new research”. Paper presented to the International Public Relations Research Symposium, Bled, Slovenia.

Grunig, L.A. (et al.), Excellent Public Relations and Effective Organizations: A Study of Communication Management in Three Countries, Lawrence Erlbaum Associates, Hillsdale 2002.

Grunig J.E. (1993) “Image and Substance:from Symbolic to Behavioral Relationships, Public Relations Review 19(2): 121 - 139

Grunig J.E. \& Repper F.C. (1992) Strategic management, publics, issues. In Grunig, J. (ed.), Excellence in

Public Relations and Communication Management, Lawrence Erlbaum Associates, Hillsdale.

Grunig J.E. \& Hunt T. (1984) Managing public relations, Forth Worth: Harcourt Brace Jovanovich College Publishers

Hatch M.J. \& Schultz M. (2002) The dynamics of organizational identity, Human Relations, 55 (8): 1004

Hillman, A.J., Keim G.D., Luce, R.A., (2001)"Board Composition and stakeholder performance: do Stakeholder directors Make a Difference?". Business \& Society. 40(3). pp. 295-314.

Jaques, E. (1995) “Social systems as a defence against persecutory and depressive anxiety". In Klein. M. et al (ed) New directions in psychoanalysis. London: Tavistock.pp.478-498.

Jawahar I.M., MCLaughlin, G.L. ,(2001) “Toward a descriptive stakeholder theory: an organizational life cycle approach”. Academy of Management Review. 26(3).pp. 397-414.

Jonker J., \& Foster, D. (2002) "Stakeholder excellence? Framing the evolution and complexity of a stakeholder perspective of the firm”. Corporate Social Responsibility and Environment Management. 9. pp. 187-195.

Kaptein M, 1998. "The Ethics Thermometer: an audit-tool for improving the corporate moral reputation". Corporate Reputation Review. 2(1). pp. 10-15.

Kennedy, S.H. (1977) "Nurturing Corporate images, Total communication or Ego Trip”. European Journal of Marketing.11. pp. 120164.

Lewellyn, P.G. (2002) Corporate Reputation: Focusing the Zeitgeist. Business \& Society. 41(4): 446-455

Luoma, P. \& Goodstein J., (1999) Stakeholders and corporate boards: institutional influences on board composition and structure". Academy of management Journal. 42(5). pp. 553-563.

Mael F. \& Ashforth B.E. (1992) Alumni and their alma mater: a partial test of the reformulated model of organizational identification. Journal of Organizational Behavior. 13. pp.103-123.

Whetten D.A. \& Makey A. (2002) A social actor Conception of organizational identity and its implications for the study of organizational reputation. Business \& Society, 41(4): 393-414

Mead, G.H., (1934) Mind, self and society. Chicago: University of Chicago press.

Mitchell, R.K., Agle, B.R., \& Wood D.J., (1997) “Toward a theory of stakeholder identification and salience : defining the Principle of who and what really counts". Academy of management review. 22(4). pp. 853-886.

Pratt, G.M. \& Foreman P.O., (2000) Classifying Managerial Responses to Multiple organizational identities”. Academy of Management Review. 25(1). pp. 18-42.

Rindova V.P. \& Fombrun C.J. (1999) "Constructing competitive advantage: the role of firm-constituent interactions". Strategic Management Journal. 20. pp. 691-710.

Rindova V.P. (1997) "The Image cascade and the formation of corporate reputations" .Part VII: Managing Reputation: Pursuing Everyday Excellence. Corporate Reputation Review. 1(2).

Savage, G.T., Nix T.W., Whitehead, C.J., and John D.B., (1991) "Strategies for assessing and managing organizational stakeholders". Academy of management Executive. 5(2). pp.61-75. 
Schlenker, B.R., (1985) "Identity and Self-identification". In Schlenker B.R., (Ed.) The self and social life. New York: McGraw-Hill. pp. 65-99.

Stuart, H., (1999). "Towards a definitive model of the corporate identity management process". Corporate Communications: An international Journal. 4(4). pp. 200-207.

Tajfel, H. ( 1982) Social identity and intergroup relations. Cambridge: Cambridge university Press.

Tajfel, H., \& Turner, J.C., (1985) “The social identity theory of intergroup behavior”. In Worchel S. \& Austin W.G. (Eds.)

Psychology of inter-group relations. Chicago:Nelson-Hall. pp. 7-24.

van Riel, C.B.M. \&Carroll, C.E. (2001) "We who are many form one body: The impact of multiple identities on organizational identification", Draft: December 15, 2001 (unpublished). Prepared For Whetten \& van RIal's Special Organizational Identity Workshop. Amsterdam.

van Riel, C.B.M., Smidts, A., \& Pruyn, A., (2001) “The impact of Employee Communication and Perceived External Prestige on Organizational Identification”. Academy of management Journal. Vol 49. No 5. pp.1051-1062.

Waddock, S.A. \& Graves S.B., (1997) “Quality of management and quality of Stakeholder Relations. Are they Synonymous?”. Business \& Society. 36(3). pp. 250-279.

Whetten, D.A., \& Makey, A., (2002) “A Social Actor Conception of Organizational Identity and Its Implications for the Study of Organizational Reputation”. Business \& Society. 41(4). pp. 393-414.

Windson, D. (1992) "Stakeholder management in multinational enterprises, In Brenner, S.N. \& Waddock S.A. (Eds.) Proceedings of the Third Annual Meeting of the International Association for Business and Society. Belgium. pp.121-128.

Winn M.I. (2001) “Building stakeholder theory with a decision modelling methodology”. Business \& Society. 40(2). pp. $133-166$. 